\title{
The Implementation of Special Needs School Programs as Resource Center for Inclusive Education in Indonesia
}

\author{
Bahrudin; Indra Jaya; Cecep Kustandi \\ Universitas Negeri Jakarta, Jakarta, Indonesia \\ http://dx.doi.org/10.18415/ijmmu.v8i12.3338
}

\begin{abstract}
This research is on the Implementation of special needs schools as Resources Center for Inclusive Education in Jakarta, Indonesia. This study aims to determine the implementation of special needs schools as organizers of inclusive educational resource centers. This research was conducted in a special needs school designated as an inclusive education resource center numbering 18 schools in Jakarta. This research uses a qualitative approach. Implementing the special needs schools' program as a resource center for inclusive education illustrates that the condition of inclusive education has not been maximized because there is still a lack of means to support the activities of inclusive educational resource centers. In addition, the need for training on inclusive education for teachers and education personnel becomes important for inclusive schools to do.
\end{abstract}

Keywords: Outstanding Schools; Resource Centers; Inclusive Education

\section{Introduction}

Special needs schools had evolved before inclusive education was rolled out(Barnett et al., 2018). According to Pei and Sonoyama (2020), special needs schools are relatively better equipped to serve education for students with special needs because it has human resources and infrastructure and special facilities and devices that are very supportive(Bantjes et al., 2015). While regular schools as a startup of inclusive education organizers still have many limitations(Lancaster \& Bain, 2021). Therefore, special needs schools need to develop their main task and function to be a source center in supporting the implementation of inclusive education in the surrounding regular schools (Jørgensen et al., 2021).

Research by Armstrong et al. (2021) explained that the implementation of inclusive education is feared not going well because many teachers in inclusive schools do not understand children with special needs and educational services for children with special needs. For that reason, inclusive education held in regular schools urgently needs technical support, especially educational services for children with special needs (Holmqvist \& Lelinge, 2020). Therefore, many programs help organize inclusive education by utilizing special needs schools asresource centers (Pedaste et al., 2021). 
In the implementation of inclusive education, there needs to be a support system needed to accelerate the fulfillment of access and improve the quality of education for all(Khamzina et al., 2021). It is because support systems can take the form of government policies or regulations and support from supporting agencies (Hassanein et al., 2021).

According to Hofmann and Muller (2021), the resource center is an institution formed by the government or community to provide support services for regular schools that organize inclusive education technically and consultatively. This support service facilitates and optimizes the implementation of inclusive education so that there is continuity and success of education for children with special needs (Heyder et al., 2020).

Research by Acosta et al. (2021) explained that a resource center is a unit in an institution (especially schools and universities) that plays a role in encouraging the effectiveness and optimization of the learning process. In its implementation, the resource center has various functions that include service functions (such as media services, training, and learning consulting)(Helmer et al., 2020). In general, resource centers have a primary mission in developing learning services, but some focus on only one service(Šiška et al., 2020). Therefore, the resource center is the framework for developing special education that all children can utilize, especially children with special needs(Banks et al., 2015). According to Ge and Tian (2021), the resource center can be assisted people with special needs, general teachers, and parents. So, resource centers can support children with special needs in the system of education services, advocacy, and self-actualization wherever children are and services to other communities and institutions in need (Susilawati et al., 2020).

Special needs schools as resource centers should develop strategic plans in implementing inclusive education. The strategic plan that the school can carry out with special needs as a resource center is formulating the vision and mission to implement inclusive education (Killedar \& Khot, 2021). To further develop the process towards inclusion, exceptional schools must be transformed into resource centers. This resource center should work with public schools to provide maximum service for all children who need extra support on an ongoing basis, at certain times, or in certain areas(Meynert, 2014). This research aims to obtain data on the implementation of special needs schools as a resources center for inclusive education in schools.

\section{Method}

This research uses descriptive qualitative methods (Sparkes \& Smith, 2014). Qualitative descriptive research aims to describe and describe the phenomenon of special needs schools as a resource center for inclusive education in schools. So, this research was conducted on the organizers of special needs schools as inclusive education resource centers in Jakarta, which amounted to 18 schools. The data collection was conducted through interviews with ten special education teachers and eight principals from the Inclusive Education Resource Center coordinator in Jakarta. In this study, researchers recorded all the answers from respondents as they were. The interviewer occasionally intersperses the respondent's answer, both to ask for an explanation or to straighten out an answer that deviates from the question. The type of interview used in this study was a structured interview. In conducting interviews, researchers have prepared research instruments in written questions. For that reason, to maintain the research code of conduct, the participants' name was Z1-Z10 for special education teachers and J1-J8 for principals.

Data analysis in this study is carried out at the time of data collection and after completing data collection within a certain period. At the interview, the researchers had already analyzed the interviewees' answers. In addition, activities in qualitative data analysis are carried out interactively and take place continuously until complete so that the data is saturated (Bowen, 2009). 


\section{Results and Discussions}

\section{Special Needs School as a Source Center}

In the Decree of the Head of Education Office of Jakarta No. 379/2011 on the Appointment of Inclusive Education Resource Center of Jakarta is in the framework of the smooth provision of educational services for students who are in special needs and guidance for inclusive school teachers in order to be able to provide appropriate educational services for children with special needs. This program can be specially established through private and public special needs schools and qualified to be a resource center. Therefore, special needs school is relatively better equipped to serve education for students with special needs because it has human resources and infrastructure and special facilities and devices that are very supportive. Moreover, special needs school needs to be developed their main task and function to be a resource center in supporting the implementation of inclusive education in the surrounding regular schools.

Starting from the 2016/2017 school year, the Jakarta regional government issued a policy that every public school from elementary to high school must accept children with special needs. This policy impacts the need for inclusive schools in education services for children with special needs so that inclusive education resource centers are needed in supporting inclusive education. The findings showed that the role of special needs school as a source center in the implementation of inclusive education has initiatives and actively implements and socializes inclusive education by providing information in various media. In addition, a special needs school learning resource center also provides support to schools (schools providing inclusive education) in implementing inclusive education. The findings also show that special needs schools as information and innovation centers in the field of special education and inclusive education can collaborate and build networks with others to improve the implementation of inclusive education.

"The special needs school as a source center in implementing inclusive education to establish partnerships with inclusive schools, provide braille and audio books for visually impaired learners, special guidance teacher services, educational services for classroom teachers/subjects, and provide learning media." ( $\mathrm{J} 1,2021)$

"The function of the resource center can be carried out by schools designated as inclusive educational resource centers, and each designated school can create or structure programs following its function. So, the special needs school as an inclusive education resource center can provide information to the school that organizes the education. In addition, providing regular assessment assistance to special needs students" $(\mathrm{J} 3,2021)$

The interview results showed that special needs schools are needed in organizing inclusive education. One of them is a statement on children with special needs in inclusive education practices. According to Mangope, Kuyini dan Major (2012), assessment practices and inclusive setting play an important role in educational processes; the ultimate goal of educational assessment is to provide an appropriate program and treatment plan for the student.

"To support the successful implementation of inclusive education, the existing special needs school needs to be empowered to have a broader task and function, namely as a support system or resource center for inclusive education organizing schools in the immediate region. $(\mathrm{Z} 2,2021)$

"The importance of resource centers in the implementation of inclusive education is also based on the current conditions that the implementation of inclusive education tends not to be optimal. $(\mathrm{Z5}, 2021)$ 
The implementation of the inclusion education center program carried out by special needs schools can be seen from various aspects, among others, with the implementation of the education service process and special companion teacher services. The interview results illustrate that the condition of inclusive education has not been maximized because there is still a lack of means to support the activities of inclusive educational resource centers. In addition, the need for training on inclusive education for teachers and education personnel becomes important for inclusive schools to do.

"In my opinion, a joint evaluation of the implementation of the inclusive educational resource center program must be carried out. This is in order to provide a record for those of us who organize inclusive education in improving services." (J5, 2021)

The interview results showed that the education services program for children with special needs at the center of inclusive educational resources includes assessment of children with special needs and implementation of educational services following the program that has been created. Thus, evaluation becomes important in improving inclusive education in schools. This is in line with Lee et al. (2015); before starting with the preparation of learning programs, teachers must know the level of functioning of children. Therefore, assessment becomes an effort to get information about the obstacles and abilities that already have and the needs that must be met for schools that organize inclusive education. This is needed to be used as a basis to make learning programs by the individual abilities of children. Based on the study findings, the implementation of assessments for children with special needs is good or meets the evaluation criteria. Special guidance teachers in the implementation of the role as an inclusive education resource center to perform educational services for special needs children following the program/work plan for the implementation of guidance/consultation services for teachers and parents of children with special needs in inclusive schools shows that special guidance teachers have guided school teachers of inclusive education organizers. However, three of the ten teachers had not fully carried out guidance. As for guidance and training regarding handling special needs children at home to parents of students still tend to be less good.

"The constraints of the implementation of activities carried out by the resource center in the organizing school are more due to the lack of supporting funds, especially the transportation of special guidance teachers and human resources or special guidance teachers are also inadequate. (J6, 2021).

The interview results showed that poor training regarding the handling of domestic workers at home due to inadequate human resources and lack of supporting funds. On the other hand, the inclusive education system in Indonesia is not new. So, it should be able to be well organized. However, the general public still thinks that this education system is relatively new in Indonesia. An inclusive education system is an educational service for children with disabilities placed in regular schools with other regular children.

Providing information or information in the form of socialization about children and forms of inclusive education services to parents of regular students and the community is one of the functions of special needs schools as a center for inclusive education resources (Khamzina et al., 2021). Therefore, in its implementation, data shows that special guidance teachers carry out socialization about children with special needs and inclusive education to parents of regular students and the community. Inclusive education resource centers have obligations and responsibilities in helping smooth the learning process in schools (Kim, 2014). Therefore, special needs schools are obliged to do two things, namely monitoring and evaluation, monitoring, and evaluation conducted by the principal or coordinator of the source center to find out the development of program implementation in accordance with the plan or not and find the advantages and disadvantages of certain activities (Bantjes et al., 2015). The data obtained show that the implementation of monitoring and evaluation related to educational service activities for children with special needs and guidance / consultative activities for inclusive school teachers conducted by principals 
and resource center coordinators is classified as good. At the same time, the special guidance teacher evaluates the program that has been implemented with the school. This study shows that the Jakarta regional government's policies provide opportunities for children with special needs to receive inclusive education.

The presence of inclusion education facilitates the expectations and expectations of students in the future. The role of a special guidance teacher is a series of behaviors performed in various ways by a special guidance teacher to carry out his or her duties. In this case, the role of a special guidance teacher is to be a mediator. Mediator means intermediary, mediator. So the special guidance teacher has the right to mediate all problems experienced by children with special needs, one of which is the ability to count the sum of integers in practice. The activity carried out by a special guidance teacher when becoming a mediator is to provide teaching.

\section{Conclusion}

This research concluded that implementing the special needs school program as a resource center for inclusive education provides services to children with special needs on a continuing basis. In addition, provide guidance and consultative services to school teachers who provide sustainable, inclusive education. Thus, it is expected that children with special needs can be educated together with other normal children through inclusion education. The goal is that there is no gap between children with special needs and other normal children. Also, maintaining children with special needs can maximize the potential that is in him.

\section{Reference}

Acosta, M. E., Matsuzaki, M., Slater, S. J., \& Sanchez-Vaznaugh, E. V. (2021). Physical activity strategies in low-resource elementary schools: Why and how are they prioritized? Preventive Medicine Reports, 23. https://doi.org/10.1016/j.pmedr.2021.101430

Armstrong, A. C., Johansson-Fua, S., \& Armstrong, D. (2021). Reconceptualising inclusive education in the Pacific. International Journal of Inclusive Education, 1-14. https://doi.org/10.1080/13603116.2021.1882057

Banks, J., Frawley, D., \& McCoy, S. (2015). Achieving inclusion? Effective resourcing of students with special educational needs. International Journal of Inclusive Education, 19(9), 926-943. https://doi.org/10.1080/13603116.2015.1018344

Bantjes, J., Swartz, L., Conchar, L., \& Derman, W. (2015). When they call me cripple: a group of South African adolescents with cerebral palsy attending a special needs school talk about being disabled. Disability and Society, 30(2), 241-254. https://doi.org/10.1080/09687599.2014.997352

Barnett, E. R., Yackley, C. R., \& Licht, E. S. (2018). Developing, implementing, and evaluating a traumainformed care program within a youth residential treatment center and special needs school. Residential Treatment for Children and Youth, 35(2), 95-113. https://doi.org/10.1080/0886571X.2018.1455559

Bowen, G. A. (2009). Document analysis as a qualitative research method. Qualitative Research Journal, 9(2), 27-40. https://doi.org/10.3316/QRJ0902027 
Ge, X., \& Tian, X. (2021). Strategies for the Architectural Space Design of Special Education Resource Center in China. Advances in Civil Engineering, 2021, 1-16. https://doi.org/10.1155/2021/6533900

Hassanein, E. E. A., Alshaboul, Y. M., \& Ibrahim, S. (2021). The impact of teacher preparation on preservice teachers' attitudes toward inclusive education in Qatar. Heliyon, 7(9). https://doi.org/10.1016/j.heliyon.2021.e07925

Helmer, J., Kasa, R., Somerton, M., Makoelle, T. M., \& Hernández-Torrano, D. (2020). Planting the seeds for inclusive education: one resource centre at a time. International Journal of Inclusive Education, 1-17. https://doi.org/10.1080/13603116.2020.1864791

Heyder, A., Südkamp, A., \& Steinmayr, R. (2020). How are teachers' attitudes toward inclusion related to the social-emotional school experiences of students with and without special educational needs? Learning and Individual Differences, 77. https://doi.org/10.1016/j.lindif.2019.101776

Hofmann, V., \& Müller, C. M. (2021). Language skills and social contact among students with intellectual disabilities in special needs schools. Learning, Culture and Social Interaction, 30. https://doi.org/10.1016/j.lcsi.2021.100534

Holmqvist, M., \& Lelinge, B. (2020). Teachers' collaborative professional development for inclusive education. European Journal of Special Needs Education, 36(5), 819-833. https://doi.org/10.1080/08856257.2020.1842974

Jørgensen, C. R., Dobson, G., \& Perry, T. (2021). Migrant children with special educational needs in European schools-a review of current issues and approaches. European Journal of Special Needs Education, 36(3), 438-453. https://doi.org/10.1080/08856257.2020.1762988

Khamzina, K., Jury, M., Ducreux, E., \& Desombre, C. (2021). The conflict between inclusive education and the selection function of schools in the minds of French teachers. Teaching and Teacher Education, 106. https://doi.org/10.1016/j.tate.2021.103454

Killedar, S. A., \& Khot, N. (2021). Inclusive Education for Persons with Disabilities : A case study of Resource Centre for Inclusive Education in Shivaji University, Kolhapur. Library Philosophy and Practice.

Kim, Y. W. (2014). Inclusive education in South Korea. International Journal of Inclusive Education, 18(10), 979-990. https://doi.org/10.1080/13603116.2012.693402

Lancaster, J., \& Bain, A. (2021). Do judgements about pre-service teachers' self-efficacy covary with their capacity to design and deliver evidence-based practice? International Journal of Inclusive Education, 25(7), 827-842. https://doi.org/10.1080/13603116.2019.1579873

Lee, F. L. M., Yeung, A. S., Tracey, D., \& Barker, K. (2015). Inclusion of Children With Special Needs in Early Childhood Education: What Teacher Characteristics Matter. Topics in Early Childhood Special Education, 35(2), 79-88. https://doi.org/10.1177/0271121414566014

Meynert, M. J. (2014). Inclusive education and perceptions of learning facilitators of children with special needs in a school in Sweden. International Journal of Special Education, 29(2), 1-18.

Pedaste, M., Leijen, Ä., Kivirand, T., Nelis, P., \& Malva, L. (2021). School leaders' vision is the strongest predictor of their attitudes towards inclusive education practice. International Journal of Inclusive Education, 1-17. https://doi.org/10.1080/13603116.2021.1994661

Pei, H., \& Sonoyama, S. (2020). Skill Building for Teachers at a Chinese Special Needs School through 
International Videophone Teleconsultation: Helping Teachers Develop and Improve Choice-making in Students with Intellectual Disabilities. International Journal of Disability, Development and Education, 00(00), 1-17. https://doi.org/10.1080/1034912X.2020.1819530

Šiška, J., Bekele, Y., Beadle-Brown, J., \& Záhořík, J. (2020). Role of resource centres in facilitating inclusive education: experience from Ethiopia. Disability and Society, 35(5), 811-830. https://doi.org/10.1080/09687599.2019.1649120

Sparkes, A. C., \& Smith, B. (2014). Qualitative Research Methods in Sport, Exercise And Health: From Process To Product. Routledge.

Susilawati, S. Y., Ummah, U. S., Pradipta, R. F., \& Dewantara, D. A. (2020). Resource Center as Support System on Inclusive Education in Malang. Jurnal Ortopedagogia, 6(2), 113-119.

\section{Copyrights}

Copyright for this article is retained by the author(s), with first publication rights granted to the journal.

This is an open-access article distributed under the terms and conditions of the Creative Commons Attribution license (http://creativecommons.org/licenses/by/4.0/). 